\title{
DYNAMICS OF MYCOTOXIN ACCUMULATION IN SILAGE DURING STORAGE
}

\author{
G.Yu. LAPTEV, N.I. NOVIKOVA, L.A. IL'INA, \\ E.A. YYLDYRYM, V.V. SOLDATOVA, I.N. NIKONOV, \\ V.A. FILIPPOVA, E.A. BRAZHNIK, O.N. SOKOLOVA
}

Biotrof+ Ltd, 7-N, 8, lit. A, Malinovskaya ul., St Petersburg_Pushkin, 196602 Russia, e-mail deniz@biotrof.ru Supported by the Russian Science Foundation, the project № 14-16-00114

Received September 8, 2014

\section{Abstract}

The presence of mycotoxins in the feeds is a big problem in the world. Result of improper silaging is the occurrence of mycotoxins, the metabolic products of molds. Today there is too little information on the accumulation of mycotoxins in silage during ensiling, and there is no answer to the question how to resolve this problem. This article includes results of mycotoxins' analysis (aflatoxins, ochratoxin A, T-2 toxin, zearalenone, deoxynivalenol) in the original forage plant material of cocksfoot Dactylis glomerata L. and in the silage at various stages of experimental ensilaging. Also the influence of biological preparations Biotrof and Biotrof-111 (Biotrof+ Ltd, Russia) and chemical preparations AIV 3 Plus and AIV 2000 Plus (KEMIRA OYJ, Finland) for the preservation of silage on reducing the amount of toxic fungal metabolites was investigated. Analysis of the amount of mycotoxins in the samples was performed by the enzyme immunoassay method using ELISA test kit AgraQuant ${ }^{\mathrm{TM}}$ (Romer Labs, Inc., Austria). Analysis of the accumulation of mycotoxins in feed plant material and silage showed that mycotoxins already occurred in forage plants as a result of fungal attacks during the growing season and later in the silages if conditions were suitable for mold growth. The biological preparations for ensiling effectively decrease the accumulation of mycotoxins in the silage compared to the variant without supplementation. At the end of silage storage the amount of aflatoxins in the variants with Biotrof and Biotrof-111 was lower by 17.7 and $9.1 \%$, respectively, compared to the control, with a decrease in the value of ochratoxin A by 21.4 and $34.9 \%, \mathrm{~T}-2$ toxin by 20.1 and $32.8 \%$, zearalenone by 17.7 and $10.4 \%$, and deoxynivalenol by 0.8 and $55.8 \%$, respectively. So far as in Russia no maximum permissible concentrations are specified for mycotoxins in silage, the values for feed grain of oats, wheat and barley taxonomically close to perennial cocksfoot grass were used for comparison (corn, one more cereal crop, is not a traditional forage plant in the North West region of Russia). The greatest deterrent effect on accumulation of mycotoxins had the preparation based on Bacillus subtilis. Chemical preparation decreased the accumulation of some mycotoxins in the storage silage. However, the silage' total toxicity in presence of the chemical preparation was quite high relatively the maximum permissible concentrations used in this study as the reference values. It significantly surpassed control in the second half of storage. As it is well known, due to changes in environmental conditions the production of mycotoxins by molds increases. In this regard, in our experiment, the influence of chemical preparation has become a stress factor that caused the active synthesis of mycotoxins by molds.

Keywords: mycotoxins, forage plants, silage, maximum limit of mycotoxins content, the biological preparation for ensiling, the chemical preparation for ensiling.

Silage is considered essential in cattle diet. In case of its low quality because of nutrient losses the animals suffer from deficit of nutrients that has a negative impact on production and animal health, and eventually on the profitability in livestock. Ensured full feeding is first related to proper growing forage plants and raw material storage. Additionally to decreased biochemical parameters, an improper ensilaging results in contamination with mycotoxins, the mold metabolic products (1).

Mycotoxins, moldy feed and raw material control problems are relevant worldwide. Mycotoxins causing mycotoxicosis adversely affect production, reproductive and immune functions in animals (2). At little amount the mycotoxins repress production and weigh gain, and increase an incidence of infections. At 
long intake the immunosuppressive, cancerogenic, mutagenic, allergenic, neurotoxic and teratogenic effects, as well as repression of reproductive functions occur. Besides, different mycotoxins being usually present together can act as synergists (3).

Traditionally, mycotoxin-related problems are considered relevant to poultry and pigs rather then cattle. However, some mycotoxins possess clear antimicrobial activity thus decreasing number of helpful microorganisms such as cellulolytic bacteria, bacilli, lactate-utilizing bacteria. It may negatively influence the digestion and metabolic activity, as well as defense functions of gut microbiota. Importantly, cows with high milk production are the most sensitive to mycotoxins being less tolerant to stresses. Besides, mycotoxins being fed to the animals with moldy feeds can penetrate into milk or other human foods, so there is an increased public concern over mycotoxins related to human health. Particularly, in cow milk a residual aflatoxin $\mathrm{M}_{1}$, the aflatoxin $\mathrm{B}_{1}$ metabolite, reached $0.3-6.0 \%$ of its intake by animals (1).

To date there is too little information on the accumulation of mycotoxins in silage during ensiling, and there is no answer to the question how to resolve this problem.

This article includes the results of testing mycotoxins during an experimental ensilaging as influenced or not influenced by bacterial preparations and chemical preservant.

Technique. In model laboratory experiments we used Dactylis glo-merata L. cockfoot grass clipping harvested at stem-extention stage and $65 \%$ moisture level. Two commercial bacterial additives, the Biotrof and Biotrof-111 (Biotrof+ Ltd, Russia, $0.007 \mathrm{ml} / \mathrm{kg}$, or a liter per 150 tons of green biomass), and chemical preservants AIV 3 Plus and AIV 2000 Plus (KEMIRA OYJ, Finland, $4 \mathrm{ml} / \mathrm{kg}$, or 4 liters per ton of green biomass) were used for ensilaging. Ensilaging biomass $(320 \mathrm{~g})$ was kept at $26 \pm 1{ }^{\circ} \mathrm{C}$, and the probes for mycotoxin testing were sampled before the ensilage start and on days 3, 7, 14 and 30 .

Mycotoxins, particularly aflatoxins, ochratoxin A, T-2 toxin, zearalenone, deoxynivalenol, were ELISA-tested (4) using a AgraQuant ${ }^{\mathrm{TM}}$ kit (Romer Labs, Inc., Austria) according to the manufacturer's recommendations with standard preparations of five mycotoxins as a control. For mycotoxin extraction, except deoxynivalenol, $70 \%$ methanol was used, and deoxynivalenol was extracted with distilled water. The tests for zearalenone and T-2 toxin were terminated by adding $10 \% \mathrm{HCl}$, and for aflatoxins, ochratoxin A and deoxynivalenol $10 \%$ phosphoric acid was used to stop the reaction. $\mathrm{OD}_{450}$ were measured on a microstrip photometer Stat Fax 303+ (Awareness Technology, Inc., USA), comparing samples to the standards. As far as in Russia the allowed level of mycotoxins in silage are not still specified and regulated, we used maximum permissible concentrations (MPCs) for forage grain of wheat, oats and barley most close taxonomically to perennial pants like cockfoot grass as referent values. Based on veterinary and sanitation requirements approved by EuriAsEU Custom Commission (№ 137 dated June 18, 2010), they were as follows: $0.004 \mathrm{mg} / \mathrm{kg}$ for aflatoxins, $0.005 \mathrm{mg} / \mathrm{kg}$ for ochratoxin A, $0.06 \mathrm{mg} / \mathrm{kg}$ for T-2 toxin, $0.1 \mathrm{mg} / \mathrm{kg}$ for zearalenone and $1.0 \mathrm{mg} / \mathrm{kg}$ for deoxynivalenol (5).

Data were processed by dispersion analysis (6) in Microsoft Excel 2010.

Results. Biotrof is a biopreparation of helpful bacteria identified as Lactobacillus plantarum according to 16SrRNA gene sequence (7). It was designed for preserving different crops, including cured plant biomass with reduced moisture. At ensilaging an acidification is rapidly achieved due to Biotrof because of lactic acid production and repression of undesirable microbial activity (8). Biotrof-111 is a 16SrRNA gene sequence identified Bacillus subtilis biopreparation applicable 
for ensilaging any crop, including those hard to silage such as legumes mixed with cereals, galega, alfala, etc. Due to high antagonistic activity it depresses putrid bacteria, mycotoxin-producing molds and yeasts providing accelerated preservation, so the silage is ready to use in less time (9). AIV chemicals contain a mix of organic acids such as formic, propionic, benzoic.

Before ensilaging, in forage plant raw material we identified aflatoxins at $0.0053 \pm 0.00025 \mathrm{mg} / \mathrm{kg}$, zearalenone at $0.0115 \pm 0.00048 \mathrm{mg} / \mathrm{kg}$ and deoxynivalenol at $1.3 \pm 0.0062 \mathrm{mg} / \mathrm{kg}$ (Table), the aflatoxins and deoxynivalenol levels being 1.3 times as much as those we used as referent values. Therefore, forage plant contamination by mycotoxins is formed in field conditions during plant vegetation and resulted from activity of phytopatogenic fungi. Of note, the ochratoxin A and T-2 toxin levels were below the reliability of ELISA estimation.

Mycotoxin content (mg per $1 \mathrm{~kg}$ of dry matter) in cockfoot grass Dactylis glomerata L. silage depending on used preparations ( $M \pm m$, laboratory experiments)

\begin{tabular}{|c|c|c|c|c|c|c|c|}
\hline \multirow{3}{*}{ Days } & \multirow{3}{*}{$\begin{array}{l}\text { Control } \\
\text { (C), } \mathrm{mg} / \mathrm{kg}\end{array}$} & \multicolumn{4}{|c|}{ Biopreparations } & \multirow{2}{*}{\multicolumn{2}{|c|}{ Chemical preservant }} \\
\hline & & \multicolumn{2}{|c|}{ lactobacilli-based } & \multicolumn{2}{|c|}{ bacilli-based } & & \\
\hline & & $\mathrm{mg} / \mathrm{kg}$ & to $\mathrm{C}, \%$ & $\mathrm{mg} / \mathrm{kg}$ & to $\mathrm{C}, \%$ & $\mathrm{mg} / \mathrm{kg}$ & to $\mathrm{C}, \%$ \\
\hline \multicolumn{8}{|c|}{ A fla t o x in s $(\mathrm{MPC}=0.004 \mathrm{mg} / \mathrm{kg})$} \\
\hline 0 & $0.0053 \pm 0.00025$ & $0.0053 \pm 0.00025$ & & $0.0053 \pm 0.00025$ & & $0.0053 \pm 0.00025$ & \\
\hline 3 & $0.0101 \pm 0.00040$ & $0.0088 \pm 0.00040$ & 87.1 & $0.0057 \pm 0.00026$ & 56.4 & $0.0110 \pm 0.00040$ & 108.9 \\
\hline 7 & $0.0113 \pm 0.00047$ & $0.0086 \pm 0.00042$ & 76.1 & $0.0092 \pm 0.00043$ & 81.4 & $0.0152 \pm 0.00065$ & 134.5 \\
\hline 14 & $0.0213 \pm 0.00800$ & $0.0184 \pm 0.00070$ & 86.4 & $0.0198 \pm 0.00080$ & 93.0 & $0.0270 \pm 0.00094$ & 126.8 \\
\hline 30 & $0.0209 \pm 0.00100$ & $0.0172 \pm 0.00060$ & 82.3 & $0.0190 \pm 0.00047$ & 90.9 & $0.0144 \pm 0.00071$ & 68.9 \\
\hline \multicolumn{8}{|c|}{$\mathrm{O}$ ch ratoxin $\mathrm{A}(\mathrm{MPC}=0.005 \mathrm{mg} / \mathrm{kg})$} \\
\hline 0 & $<$ bre & $<$ bre & & $<$ bre & & $<$ bre & \\
\hline 3 & $0.0068 \pm 0.00023$ & $0.0053 \pm 0.00020$ & 77.9 & $0.0060 \pm 0.00025$ & 88.2 & $0.0089 \pm 0.00040$ & 130.8 \\
\hline 7 & $<$ bre & $<$ bre & & $0.0003 \pm 0.00001$ & & $0.0009 \pm 0.00003$ & \\
\hline 14 & $0.0127 \pm 0.00059$ & $0.0059 \pm 0.00023$ & 46.5 & $0.0031 \pm 0.00015$ & 24.4 & $0.0739 \pm 0.00310$ & 581.9 \\
\hline 30 & $0.0295 \pm 0.00140$ & $0.0232 \pm 0.00090$ & 78.6 & $0.0192 \pm 0.00058$ & 65.1 & $0.2720 \pm 0.01200$ & 922.0 \\
\hline \multicolumn{8}{|c|}{$\mathrm{T}-2$ t o $\mathrm{x}$ i n $(\mathrm{MPC}=0.06 \mathrm{mg} / \mathrm{kg})$} \\
\hline 0 & $<$ bre & $<$ bre & & $<$ bre & & $<$ bre & \\
\hline 3 & $0.0937 \pm 0.02300$ & $0.0930 \pm 0.00410$ & 99.3 & $0.1025 \pm 0.00370$ & 109.4 & $0.1089 \pm 0.00410$ & 116.2 \\
\hline 7 & $0.0391 \pm 0.01600$ & $0.0396 \pm 0.00170$ & 101.3 & $0.0140 \pm 0.00048$ & 35.8 & $0.0336 \pm 0.00160$ & 85.9 \\
\hline 14 & $0.1221 \pm 0.00370$ & $0.1118 \pm 0.00520$ & 91.6 & $0.0965 \pm 0.00220$ & 79.0 & $0.0834 \pm 0.00420$ & 68.3 \\
\hline 30 & $0.1116 \pm 0.00510$ & $0.0892 \pm 0.00320$ & 79.9 & $0.0750 \pm 0.00350$ & 67.2 & $0.1191 \pm 0.00480$ & 106.7 \\
\hline \multicolumn{8}{|c|}{$\mathrm{Z}$ e a r a le non e $(\mathrm{MPC}=0.1 \mathrm{M \Gamma} \mathrm{mg} / \mathrm{kg})$} \\
\hline 0 & $0.0115 \pm 0.00048$ & $0.0115 \pm 0.00048$ & & $0.0115 \pm 0.00048$ & & $0.0115 \pm 0.00048$ & \\
\hline 3 & $0.0213 \pm 0.00100$ & $0.0144 \pm 0.00036$ & 67.6 & $0.0168 \pm 0.00065$ & 78.9 & $0.0142 \pm 0.00061$ & 66.7 \\
\hline 7 & $0.0475 \pm 0.00170$ & $0.0893 \pm 0.00410$ & 188.0 & $0.0909 \pm 0.00380$ & 191.4 & $0.1167 \pm 0.00350$ & 245.7 \\
\hline 14 & $0.1514 \pm 0.00360$ & $0.1407 \pm 0.00670$ & 92.9 & $0.1345 \pm 0.00630$ & 88.8 & $0.0977 \pm 0.00320$ & 64.5 \\
\hline 30 & $0.1290 \pm 0.00610$ & $0.1062 \pm 0.00051$ & 82.3 & $0.1156 \pm 0.00460$ & 89.6 & $0.0790 \pm 0.00290$ & 61.2 \\
\hline \multicolumn{8}{|c|}{ De ox ynivale nol $(\mathrm{MPC}=1.0 \mathrm{mg} / \mathrm{kg})$} \\
\hline 0 & $1.3000 \pm 0.00620$ & $1.3000 \pm 0.00620$ & & $1.3000 \pm 0.00620$ & & $1.3000 \pm 0.00620$ & \\
\hline 3 & $0.6800 \pm 0.02800$ & $0.4200 \pm 0.01800$ & 61.8 & $0.6900 \pm 0.03450$ & 101.5 & $0.8100 \pm 0.02400$ & 119.1 \\
\hline 7 & $5.1200 \pm 0.22000$ & $4.6600 \pm 0.20000$ & 91.0 & $3.8100 \pm 0.12000$ & 74.4 & $4.1200 \pm 0.19000$ & 80.5 \\
\hline 14 & $1.4000 \pm 0.04100$ & $3.1900 \pm 0.12000$ & 227.9 & $0.9900 \pm 0.03900$ & 70.7 & $4.1700 \pm 0.20000$ & 297.9 \\
\hline 30 & $1.2900 \pm 0.05200$ & $1.2800 \pm 0.03500$ & 99.2 & $0.5700 \pm 0.02600$ & 44.2 & $1.5000 \pm 0.06500$ & 116.3 \\
\hline
\end{tabular}

On days $3,7,14$ and 30 a significant accumulation of all tested mycotoxins was found (see Table).

The graphs (Fig., A) illustrate a sharp increase in zearalenone and T-2 toxin levels at ensilaging while aflatoxins and ochratoxin A levels increased slightly compared to those in raw material. Interestingly, all tested mycotoxins, except ochratoxin A, decreased in amount in the second half of the observation, and deoxynivalenol after a sharp increase on day 3 dropped on day 7 (Fig., B).

Of note, a contamination by zearalenone, T-2 toxin and deoxynivalenol produced by Fusarium fungi is formed in field conditions during plant growth and can rise at feed storage (10). A rise of mycotoxin production is affected by changes in temperature and moisture or by chemicals (11-15). In our experiments environmental conditions, being a stress factor, probably activated synthe- 
sis of zearalenone and T-2 toxin by microscopic fungi during 0 to 14 days of storage. Thereafter, fungal growth was terminated and death occurred with further destruction of toxic metabolites due to microbial activity in the silage. Deoxynivalenol-producing fungi are likely unable to develop in silage, and after 3 day storage the deoxynivalenol was destructed by other microorganisms.

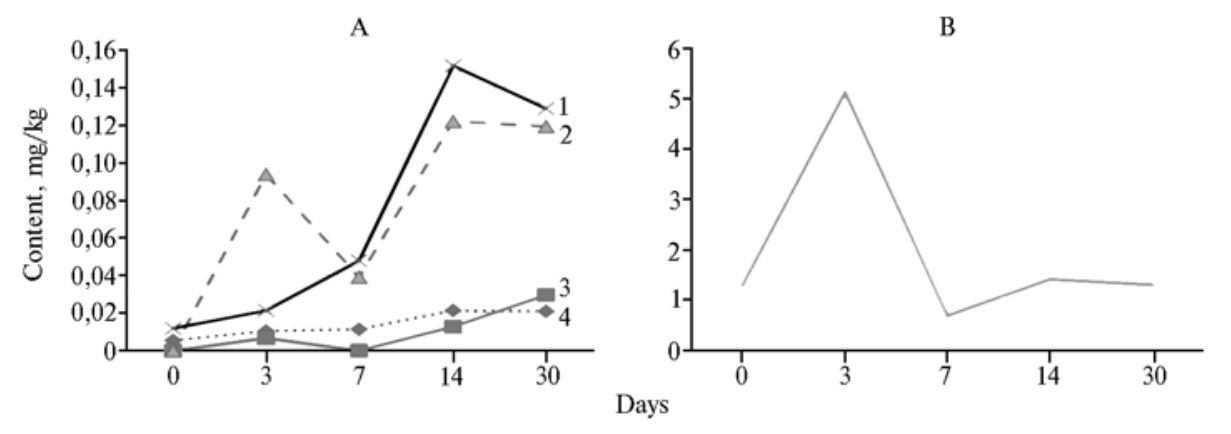

Zearalnone (1), T-2 toxin (2), ochratoxin A (3), aflatoxins (4) (A) and deoxynivalenol (B) accumulation at ensilaging cockfoot grass Dactylis glomerata $\mathrm{L}$. with no additives (laboratory experiments).

With that, the ensilaging conditions are suitable for the development of aflatoxins and ochratoxin A producing fungi of Aspergillus and Penicillium genera (10), so that they should not activate any defense mechanisms, including significant amount of mycotoxins synthesized. As a result the aflatoxins and ochratoxin A synthesis during the observation was not high.

The values of mycotixins we used as those referent were exceeded 1.46.8 times for aflatoxins, 1.2-54.4 times for ochratoxin A, 1.4-1.8 times for T-2 toxin, 1.2-1.5 times for zearalenone and 1.3-5.1 times for deoxynivalenol (see Table). Obviously, the preparation used for ensilaging should provide high preservation of nutrients and balanced protein, energy and biological value in feeds, and also restrict the accumulation of mycotoxins due to powerful antifungal properties. Some strains of lactobacilli and bacilli are known as potent repressors of microscopic fungi and destructors of their toxic metabolites (16).

Actually, during ensilaging the lacrobacilli-based Biotrof and bacillibased Biotrof-111 biopreparations provided 12.9-23.9 and 7.0-43.6 \% decreased levels for aflotoxins, respectively, if compared to control, and to the end of storage the amount of aflotoxins was lower by 17.7 and $9.1 \%$, respectively, compared to that in absence of preparations. In case the chemical preservant was used the aflatoxins levels exceeded control by $8.9,34.5$ and $26.8 \%$ on days 3,7 and 14 , respectively, while on day 30 aflatoxins dropped in amount by $31.1 \%$ compared to control.

The Biotrof and Biotrof-111 decreased significantly the ochratoxin A accumulation at ensilaging, except day 7 , when the toxic metabolite was detected at $0.0003 \pm 0.000007 \mathrm{mg} / \mathrm{kg}$ in the presence of Biotrof-111, while in control its level was below reliable detection in ELISA-test. To the end of storage the ochratoxin levels were 21.4 and $34.9 \%$ lower with Biotrof and Biotrof-111, respectively, compared to control. In presence of the chemical preservant the ochratoxin A content was increased throughout the investigation, being in the end $822 \%$ increased compared to control.

Biotrof-111 based on bacilli and chemical preservant caused some increase in T-2 toxin level on day 3, but since day 7 to the end of experiment it significantly decreased, except day 30 in the presence of preservant, when T-2 toxin content exceeded control by $6.7 \%$. A permanent decrease in T-2 toxin level was also observed from the middle to the end of storage period when Biotof, the lactobacilli based biopreparation, was used. 
Zearolenone significantly decreased in amount being influenced by both biopreparations and the chemical preservant, except day 7, when it exceeded the control level in all variants.

Biotrof-111 based on bacilli decreased deoxynivalenol level by 25.6$55.8 \%$ from day 7 to day 30 of the silage storage, while in presence of lactobacillii based Biotrof the values were about the same as in control. However, the application of chemical preservant led to a significantly increased deoxynivalenol level on days 3, 14 and 30, particularly by $16.3-197.9 \%$.

Toxic fungal metabolites in feeds, due to synergism, reciprocally complement and enhance their negative effects (17-20). So far as a combination of toxins was found, the sum of their excesses over the levels accepted hereinabove as referent values was conditionally considered as «the silage toxicity» parameter and used for estimating and comparing complex effect of the preparation tested.

During ensilaging these sums in presence of Biotrof and Biotrof-111 biopreparation were below control. The lowest value was estimated at Biotrof-111 application. The maximal value, being much higher compared to control after 14 days of preservation, was found at chemical preservant use. As mentioned, stresses, including chemicals, could activate mycotoxin production $(21,22)$, so chemical preservant could be a chemical stressor activating mycotoxin synthesis.

Thus, for the first time in Russia the mycotoxin accumulation was studied at different stages of experimental ensilaging of cereal perennial grass under the influence of different bio- and chemical additives. It was found out that the mycotoxin contamination was formed during plant vegetation, and mycotoxin production occurred during silage storage. Biopreparations based on Lactobacillus plantarum (Biotrof) and Bacillus subtilis (Biotrof-111) decreased contamination below the control level (with no additives used), and Biotrof111 was the most effective. Chemical preservant caused a decrease in some mycotoxin levels, nevertheless «the silage toxicity» as a conditional parameter we suggested to compare a total effect of a preparation used on all mycotoxins tested was higher, and after 14 days much more higher compared to control. Stimulation of mycotoxin production in microscopic fungi under environmental stress is well known. In our investigation chemical preservan can perform as a stress agent and instigate the mycotoxin synthesis. So the development of bacilli-based biopreparation destroying microscopic fungi and destructing mycotoxins in silage is obviously relevant, since chemical preservants could not provide the control of mycotoxin contamination.

\section{REFERENCES}

1. D i a z D. Mikotoksiny i mikotoksikozy [Mycotoxins and mycotoxicoses]. Moscow, 2006.

2. B e nnett J.W., Klich M. Mycotoxins. Clin. Microbiol. Rev., 2003, 16(3): 497-516 (doi: 10.1128/CMR.16.3.497-516.2003).

3. Streit E., Schatzmayr G., Tassis P., Tzika E., Marin D., Taranu I., Tabuc S., Nicolau A., A produ I., Puel O., O swald I.P. Current situation of mycotoxin contamination and co-occurrence in animal feed - focus on Europe. Toxins, 2012, 4(10): 788-809 (doi: 10.3390/toxins4100788).

4. GOST 31653-2012. Korma. Metod immunofermentnogo opredeleniya mikotoksinov. Prinyat 20 iyulya 2012 goda [Russian State Standard 31653-2012. Feeds. Immunoassay of mycotoxins. Accepted July 20, 2012].

5. Trebovaniya Komissii tamozhennogo soyuza 18 iyunya 2010 goda № 317 [Requirements of the Custom Union Commission (№ 317. Dated June 18, 2010)]. Ofitsial'nyi sait Komissii Tamozhennogo soyuza (http://www.tsouz.ru/KTS/KTS17/Pages/R 317.aspx), 2010

6. Lak in G.F. Biometriya [Biometry]. Moscow, 1990.

7. L a p t e v G.Yu. Razrabotka biologicheskikh preparatov dlya povysheniya pitatel'nosti $i$ effektivnosti ispol'zovaniya kormov. Doktorskaya dissertatsiya [Development of biopreparations to increase nutritive value and efficacy of utilization of feeds. DSc Thesis]. Dubrovitsy, 2009.

8. Laptev G., Dernov V., Roiko O. Tsenovik, 2003, 5: 10. 
9. Pobednov Yu.A., M a m a e v A.A. Zhivotnovodstvo Rossii, 2010, 8: 52.

10. Wils o n D.M., A brams on D. Mycotoxins. In: Storage of cereal grains and their products. D.B. Sauer (ed.). American Association of Cereal Chemists, Inc., St. Paul, Minnesota, 1992: 341-391.

11. Skladanka J., Adam V., Dolezal P., Nedelnik J., Kizek R., Linduskova H., E d i s o n Jh., M e ji a A., N a w r ath A. How do grass species, season and ensiling influence mycotoxin content in forage? International Journal of Environmental Research and Public Health, 2013, 10: 6084-6095 (doi: 10.3390/ijerph10116084).

12. D'M ello J.P.F., Macdonald A.M.C. Fungal toxins as disease elicitors. In: Environmental toxicology: current developments. J. Rose (ed.). Amsterdam, the Netherlands, 1998: 253-289.

13. S i m p s on D.R., We st on G.E., T u rn e r J.A., J e n n ings P., Ni cholson P. Differential control of head blight pathogen of wheat by fungicides and consequences for mycotoxin contamination. Eur. J. Plant Pathol., 2001, 107: 421-431 (doi: 10.1023/A:1011225817707).

14. Ramirez M.L., Reynoso M.M., Farnochi M.C., Chulze S. Vegetative compatibility and mycotoxin chemotypes among Fusarium graminearum (Gibberella zeae) isolates from wheat in Argentina. Eur. J. Plant Pathol., 2006, 115: 139-148.

15. I o o s R., B e $1 \mathrm{~h}$ a d j A., M e $\mathrm{n}$ e z M., F a u r e A. The effects of fungicides on Fusarium spp. and Microdochium nivale and their associated trichothecene mycotoxins in French naturallyinfected cereal grains. Crop Protect., 2005, 24: 894-902 (doi: 10.1016/j.cropro.2005.01.014).

16. Engle r K.H., Coker R.D., Evans I.H. Uptake of aflatoxin $B_{1}$ and T-2 toxin by two mycotoxin bioassay microorganisms: Kluyveromyces marxianus and Bacillus megaterium. Arch. Microbiol., 2000, 174: 381-385 (doi: 10.1007/s002030000215).

17. Palu mbo J.D., B a k e r J.L., M a h on e y N.E. Isolation of bacterial antagonists of Aspergillus flavus from almonds. Microb. Ecol., 2006, 52: 45-52 (doi: 10.1007/s00248-006-9096-y).

18. R e d dy K.R.N., Reddy C.S., M u ralidh a ra $\mathrm{n}$ K. Potential of botanicals and biocontrol agents on growth and aflatoxin production by Aspergillus flavus infecting rice grains. Food Control, 2009, 20(2): 173-178 (doi: 10.1016/j.foodcont.2008.03.009).

19. Zhang T., Shi Z.Q., Hu L.B., Cheng L.G., Wang F. Antifungal compounds from Bacillus subtilis BFS06 inhibiting the growth of Aspergillus flavus. World J. Microbiol. Biotechnol., 2008, 24: 783-788 (doi: 10.1007/s11274-007-9533-1).

20. Cho K.M., Math R.K., Hong S.Y., I s lam S.M.A., Mandanna D.K., Cho J.J., Y u n M.J., K i m J.M., Y u n H.D. Iturin produced by Bacillus pumilus HY1 from Korean soybean sauce (kanjang) inhibits growth of aflatoxin producing fungi. Food Control, 2009, 20(4): 402-406 (doi: 10.1016/j.foodcont.2008.07.010).

21. Cavaglieri L., Passone A., Etcheverry M. Screening procedures for selecting rhizobacteria with biocontrol effects upon Fusarium verticillioides growth and fumonisin $\mathrm{B}_{1}$ production. Res. Microbiol., 2004, 155(9): 747-754 (doi: 10.1016/j.resmic.2004.06.001).

22. Khan N.I., S chisle r D.A., B o e h m M.J., Slininger P.J., B othast R.J. Selection and evaluation of microorganisms for biocontrol of Fusarium head blight of wheat incited by Gibberella zeae. Plant Dis., 2001, 85(12): 1253-1258 (doi: 10.1094/PDIS.2001.85.12.1253). 